\title{
Dodatki uszlachetniające do olejów napędowych
}

\begin{abstract}
W artykule przedstawiono typowy skład pakietu dodatków uszlachetniających do nowoczesnego oleju napędowego stosowanego w silnikach z zapłonem samoczynnym. Omówiono problemy, z jakimi borykają się producenci tego rodzaju paliwa, i związki chemiczne najczęściej stosowane w celu ich rozwiązania.
\end{abstract}

Słowa kluczowe: olej napędowy, diesel, dodatki do oleju napędowego.

\section{Additives for diesel fuels}

The article presents a typical package of additives for modern diesel fuel used in compression ignition engines. The problems faced by the producers of this type of fuel and the most commonly used chemicals to resolve those problems are discussed.

Key words: fuel oil, diesel fuel, fuel oil additives.

\section{Wstęp}

W ciągu ostatnich kilkunastu lat samochody z silnikami Diesla podbiły rynek europejski. O ile w 1997 r. w silniki te było wyposażonych tylko $22 \%$ wszystkich sprzedawanych w Europie samochodów osobowych, o tyle w 2007 r. udział ten wyniósł 53,3\% i w kolejnych latach, pomimo wahań, utrzymał się na poziomie około $40 \%$ [1].

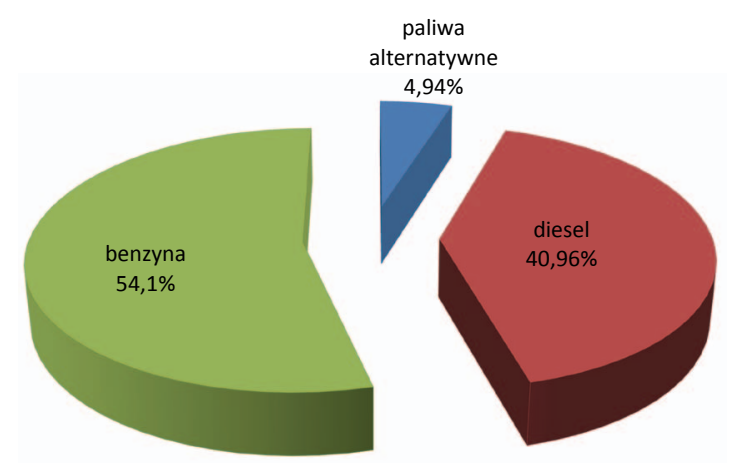

Rys. 1. Procentowy udział rodzajów napędu w samochodach osobowych zarejestrowanych w Unii Europejskiej w 2014 r. (paliwa alternatywne oznaczają: LPG (liquefied petroleum gas) propan-butan, CNG (compressed natural gas) - metan, prąd) [20]

Oznacza to, że po drogach Europy jeździ około $103 \mathrm{mln}$ samochodów osobowych z silnikami z zapłonem samoczynnym, nie zapominając o $23 \mathrm{mln}$ samochodów dostawczych i 13 mln ciężkich ciężarówek, które również są napędzane silnikami Diesla [21] - łącznie zużywają one około $200 \mathrm{mln}$ ton oleju napędowego rocznie [19].

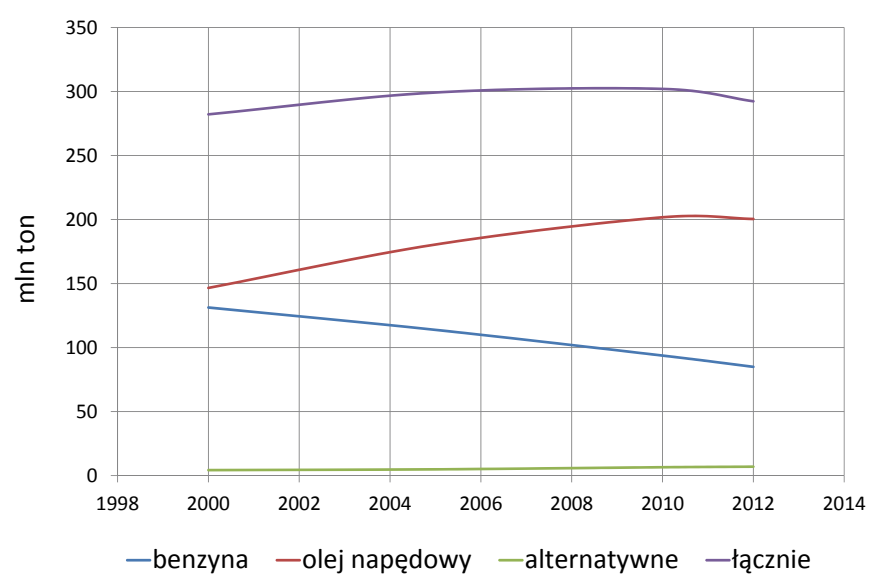

Rys. 2. Zużycie paliw w Unii Europejskiej według rodzaju paliwa, w mln ton [19]

Dlaczego nastąpił tak gwałtowny skok sprzedaży samochodów napędzanych popularnym olejem napędowym? Otóż w 1997 r. Fiat przedstawił swój silnik z bezpośrednim wtryskiem paliwa wykorzystujący technologię common rail (wspólna szyna), charakteryzujący się wysokim ciśnieniem 
panującym w układzie wtryskowym. Wprawdzie pierwszy patent na wtrysk tego typu uzyskano już w 1913 r. [31], a następnie w latach 60. dwudziestego wieku został on ulepszony [37], ale dopiero pod koniec wieku udało się ten pomysł wprowadzić do produkcji masowej.

Dzięki temu silniki z zapłonem samoczynnym, przy zachowaniu swojej głównej zalety, jaką jest niskie zużycie paliwa, pozbyły się największych wad, do których kierowcy zaliczali niską dynamikę, hałas i wibracje generowane przez jednostkę napędową oraz charakterystyczny dla diesli czarny obłok spalin wydobywający się z rury wydechowej.

Silniki z systemem common rail pierwszej generacji, w tym silnik zastosowany przez Fiata, pracowały pod ciśnieniem rzędu 1300 barów, podczas gdy w drugiej generacji silników tego typu ciśnienie to podniesiono już do około 1600 barów, a w obecnie stosowanej trzeciej gene- racji ciśnienie przewyższa 2000 barów. Ewolucja silników musiała pociągnąć za sobą również zmianę paliwa, którym te silniki były zasilane. Aby spełnić wymagania stawiane przez producentów samochodów, olej napędowy zawiera od kilku do kilkunastu dodatków uszlachetniających, stosowanych w postaci tzw. pakietów dodatków, powodujących, że jazda współczesnym samochodem napędzanym silnikiem Diesla jest jednocześnie przyjemna i względnie tania, a sam silnik może bezproblemowo pokonywać setki tysięcy kilometrów.

Dodatki uszlachetniające do oleju napędowego można podzielić na dwie główne kategorie:

- dodatki działające w układzie paliwowym i silniku samochodu,

- dodatki działające w układzie dystrybucji i magazynowania paliw.

\section{Dodatki działające w układzie paliwowym i silniku samochodu}

\section{Dodatki zwiększające liczbę cetanowa}

Liczba cetanowa to jedna z podstawowych wielkości charakteryzujących jakość oleju napędowego. Jest miarą zdolności paliwa do samozapłonu. Według obowiązującej normy [52] liczba cetanowa dla oleju napędowego powinna być nie mniejsza niż 51, natomiast najnowsza Światowa Karta Paliw z 2013 r. [53] dzieli olej napędowy na pięć kategorii i dla oleju napędowego dwóch najwyższych kategorii (IV i V), czyli sprzedawanego jako tzw. paliwa premium, zaleca, aby liczba cetanowa wynosiła minimum 55 jednostek.

Azotan 2-etyloheksylu (EHN) jest najszerzej stosowanym dodatkiem podnoszącym liczbę cetanową. Niestety, jest on nietrwały termicznie i szybko ulega rozkładowi w wysokiej temperaturze w komorze spalania $[9,10]$; produkty rozkładu mogą zainicjować spalanie paliwa, a tym samym skrócić okres opóźnienia zapłonu w stosunku do tej samej ilości paliwa bez dodatku. Dodatkowo wzrost liczby cetanowej po uszlachetnieniu EHN jest tym większy, im większa była liczba cetanowa paliwa bazowego (przed uszlachetnieniem) [2, 5], i w zależności od tego dodatek może podwyższyć liczbę cetanową od 3 do 8 jednostek. Stężenie EHN w paliwie wynosi zazwyczaj od 500 do $1000 \mathrm{mg} / \mathrm{kg}$.

Drugim dodatkiem, stosowanym w przemyśle, podnoszącym liczbę cetanową jest nadtlenek di-tert-butylu (DTBP), jednak jest on mniej skuteczny niż EHN; jego zaletą jest jednak to, że nie pogarsza właściwości termicznych paliwa i nie zawiera azotu [47].

\section{Dodatki detergentowe}

Paliwo i/lub olej silnikowy może tworzyć nagary i innego typu osady na końcówce dyszy wtryskiwacza i na ścian- kach cylindra - czyli w miejscach narażonych na działanie wysokich temperatur. Zjawisko tworzenia nagarów zależy od rodzaju silnika, składu paliwa i oleju oraz warunków pracy.

Powstające osady i nagary mogą zakłócić pracę wtryskiwacza, co z kolei może utrudnić tworzenie mieszanki paliwowo-powietrznej, zaprogramowanej przez komputer sterujący silnikiem, a to wpływa niekorzystnie na proces spalania, więc i pracę silnika, oraz powoduje wzrost emisji substancji szkodliwych, takich jak cząstki stałe PM (particulate matter). Dodatki detergentowe mają za zadanie nie dopuszczać do osadzenia się nagarów lub innych osadów na końcówkach wtryskiwaczy i cylindrów oraz oczyścić je z osadów już istniejących [32]. Cząsteczki tych dodatków składają się z grupy polarnej, która łączy się z osadami, i grupy niepolarnej, która rozpuszcza się w paliwie. Zazwyczaj są to związki z grupy amidowych lub imidowych pochodnych bezwodnika bursztynowego lub różnego typu zasady Mannicha [48]. Dodatki detergentowe są zazwyczaj stosowane w stężeniu od 50 do $250 \mathrm{mg} / \mathrm{kg}$.

\section{Dodatki smarnościowe}

Ze względów ekologicznych na terenie Unii Europejskiej stosuje się niskosiarkowy olej napędowy; zawartość siarki nie może być wyższa niż $10 \mathrm{mg} / \mathrm{kg}$. Związki zawierające siarkę w oleju napędowym są źródłem emisji dwutlenku siarki do atmosfery oraz przyczyną tworzenia nagarów, powodujących uszkodzenia silnika. Ze względu na klimat panujący w naszej części Europy sprzedawane tu oleje napędowe powinny natomiast zawierać jak najmniej ciężkich frakcji węglowodorowych, które są przyczyną problemów z samochodami z silnikiem Diesla w okresie zimowym. 
Zmniejszenie zawartości w paliwie tych dwóch rodzajów związków, mających doskonałe właściwości smarne, skutkuje niestety obniżeniem właściwości smarnych paliwa, a co za tym idzie - wymusza zastosowanie dodatków smarnościowych. Ich działanie polega na wytworzeniu cienkiego filmu na powierzchni metalowych części silnika, co obniża tarcie. Najczęściej są to kwasy monokarboksylowe, amidy lub estry. Najskuteczniejsze są kwasy, i z tego względu stosuje się je w najmniejszej ilości (od 10 do $50 \mathrm{mg}$ na kilogram paliwa), natomiast estry i amidy, ze względu na mniejszą polarność, muszą być używane w stężeniu od 50 do $250 \mathrm{mg} / \mathrm{kg}$ [13].

\section{Dodatki FBC (fuel-borne catalyst)}

Najnowocześniejsze z produkowanych obecnie samochodów z silnikami Diesla są wyposażone w filtry cząstek stałych (DPF - diesel particulate filter), które mają za zadanie zmniejszenie ilości cząstek stałych w spalinach. Zostało to wymuszone na producentach pojazdów spalinowych przez wprowadzanie coraz to bardziej rygorystycznych norm emisji spalin w samochodach sprzedawanych na terenie Unii Europejskiej.

Począwszy od 1993 r., kiedy to zaczęła obowiązywać norma Euro I, do dzisiaj, gdy obowiązuje norma Euro VI, dopuszczalna ilość cząstek stałych w spalinach zmniejszyła się z 0,36 do $0,01 \mathrm{~g} / \mathrm{km}$.

Ponieważ filtry znajdujące się w układzie wydechowym silnika zatrzymują cząstki stałe, z czasem ulegają tzw. zablokowaniu, co wiąże się z dużym wzrostem oporów przepływu gazów odlotowych w układzie filtra i zaburzeniami w pracy silnika, i konieczne jest wprowadzenie metod ich efektywnej regeneracji.

Ponieważ stosowanie aktywnie regenerowanych filtrów DPF pociąga za sobą zwiększenie kosztów produkcji i wzrost komplikacji, a co za tym idzie - potencjalnej usterkowości samochodów, dąży się do wykorzystywania filtrów regenerowanych pasywnie.

W tym celu wprowadza się do paliwa dodatki FBC, zwane katalizatorami utleniania sadzy. Ich zadaniem jest obniżenie temperatury, w której następowałoby wypalenie osadzającej się sadzy, do wielkości osiąganej w trakcie normalnej pracy silnika.

Dodatki FBC, oprócz tego, że muszą być skuteczne, to muszą również być stabilne w paliwie, dlatego są to organorozpuszczalne związki zawierające tlenki metali (jednym z najpopularniejszych jest żelazo) [11, 12, 14, 17, 18]. Stężenie stosowanych dodatków FBC wynosi zazwyczaj od 30 do $120 \mathrm{mg} / \mathrm{kg}$.

\section{Dodatki działające w układzie dystrybucji i magazynowania paliw}

Drugą kategorię dodatków stanowią substancje działające w układzie dystrybucji i magazynowania paliw. Należą do niej dodatki opisane poniżej.

\section{Środki antypienne}

Niektóre oleje napędowe mają tendencję do pienienia się w trakcie pompowania, co może zakłócać proces napełniania zbiorników, uniemożliwiając ich całkowite napełnienie, lub powodować wycieki. Większość środków antypiennych jest związkami krzemoorganicznymi lub polisilikonowymi $[1,7,23,43]$; środki antypienne dodawane są w stężeniach poniżej $10 \mathrm{mg} / \mathrm{kg}$.

\section{Dodatki przewodnościowe (antystatyczne)}

$\mathrm{W}$ trakcie pompowania paliwa, zwłaszcza gdy jest pompowane przez filtry, w układzie powstaje pewna ilość ładunków elektrostatycznych, które w normalnych warunkach są szybko rozpraszane i nie stanowią problemu dla bezpieczeństwa instalacji i obsługujących ją osób. Przy niskiej przewodności paliwa niskosiarkowego istnieje jednak możliwość gromadzenia się znacznej ilości energii. Wyładowania, które mogą wówczas wystąpić, stwarzają potencjalne ryzyko wybuchu pożaru.
W celu uniknięcia gromadzenia się ładunku statycznego w paliwie - stosowane są dodatki antystatyczne, których zadaniem jest poprawa przewodności elektrycznej paliwa. Stężenie tego typu dodatków wynosi zazwyczaj poniżej $10 \mathrm{mg} / \mathrm{kg}[7,33,46]$.

\section{Depresatory}

W składzie oleju napędowego znajdują się n-parafiny, o liczbie atomów węgla w cząsteczce od 10 do 30. Są one bardzo pożądanym składnikiem paliwa ze względu na wysoką liczbę cetanową, ale w niskich temperaturach mają tendencję do tworzenia kryształów, co może powodować zatykanie się przewodów paliwowych czy filtrów.

W celu przeciwdziałaniu temu zjawisku stosowane są tzw. depresatory, czyli związki powodujące obniżenie temperatury powstawania kryształów wosków lub zmieniające ich wielkość, kształt i/lub stopień ich aglomeracji. Są to zazwyczaj kopolimery octanu winylu, styrenu i butadienu lub polimery akrylanowe $[8,16,36,44,45]$.

\section{Inhibitory korozji}

Większość instalacji w przemyśle naftowym jest wykonana ze stali, co w obecności wody naraża je na korozję. 
Powoduje ona niebezpieczeństwo rozszczelnienia i wycieku, a wcześniej może dojść do zapchania się filtrów lub zaworów, gdy cząsteczki rdzy zostaną porwane przez strumień pompowanego paliwa.

Inhibitorami korozji są związki, które oddziałują z powierzchnią metalu i tworzą na nim barierę ochronną, zapobiegającą oddziaływaniu czynników korozyjnych. Zwykle są to różnego typu aminy, amidy, sole amoniowe czy kwasy karboksylowe, które stosuje się w stężeniu od 5 do $15 \mathrm{mg} / \mathrm{kg}$ $[6,25,39,40]$.

\section{Demulgatory}

W normalnych warunkach po wymieszaniu węglowodory i woda szybko tworzą osobne fazy. Jeśli jednak paliwo zawiera związki polarne oraz wodę, olej napędowy i woda mogą utworzyć trwałą emulsję. Przyczynia się do tego każda operacja, która powoduje mieszanie, np. pompowanie paliwa. W celu przeciwdziałania temu zjawisku wykorzystuje się dodatki zwane demulgatorami.

Demulgatorami są środki powierzchniowo czynne, które powodują rozbicie emulsji i utworzenie dwóch oddzielnych faz. Demulgatory zazwyczaj stosowane są w stężeniu od 5 do $30 \mathrm{mg} / \mathrm{kg}[22,25,27]$.

\section{Dyspergatory}

Zadaniem dyspergatorów, będących składnikiem pakietów dodatków, jest przeciwdziałanie osadzaniu się wytrąconych osadów żywicznych, co mogłoby skutkować zatkaniem filtrów. Powodują one zawieszenie tego typu osadów i nie dopuszczają do ich aglomeracji, umożliwiając tym samym przepływ paliwa przez instalację.

Środki dyspergujące na ogół stosuje się w stężeniu od 15 do $100 \mathrm{mg} / \mathrm{kg}[3,24,26]$.

\section{Dodatki biobójcze (biocydy)}

Olej napędowy powstaje w procesach wysokotemperaturowych, jest więc wolny od życia mikrobiologicznego. Jednakże może ulec skażeniu, jeśli narażony zostanie na działanie mikroorganizmów (bakterie i grzyby) występujących w powietrzu lub w wodzie.

Ponieważ większość mikroorganizmów potrzebuje do życia wody, zazwyczaj życie biologiczne rozwija się na granicy olej napędowy-woda, na dnie zbiorników magazynowych. Skutkiem tego jest powstawanie osadów z obumarłych organizmów, mogące doprowadzić do zatykania filtrów, ale również do powstawania kwaśnych produktów rozkładu, co zwiększa ryzyko korozji.

Biocydy są zazwyczaj stosowane w stężeniu od 200 do $600 \mathrm{mg} / \mathrm{kg}$. Jednak ze względu na to, że wszystkie środki biobójcze są bardzo toksyczne, najlepszym sposobem przeciw- działania występowaniu skażenia mikrobiologicznego jest niedopuszczenie do zawodnienia magazynowanego paliwa $[4,30]$.

\section{Deaktywatory metali}

Śladowe ilości niektórych metali, zwłaszcza żelaza i miedzi, mogące znajdować się w oleju napędowym katalizują reakcje powodujące niestabilność paliwa, np. powstawanie związków żywicznych, które mogą wytrącać się, tworząc osady. Deaktywatory metali wiążą metale poprzez tworzenie chelatów, przez co neutralizują ich działanie katalityczne. Są one zwykle stosowane w stężeniach od 1 do $15 \mathrm{mg} / \mathrm{kg}$. Najpopularniejszymi związkami wykorzystywanymi jako deaktywatory metali są benzotriazol i jego pochodne oraz N,N'-disalicylideno-1,2-propanodiamina [15, 34, 35].

\section{Przeciwutleniacze (antyoksydanty)}

Jedną z przyczyn niestabilności paliw są zachodzące w nich reakcje utleniania. Utlenianie występuje, gdy tlen z powietrza, które jest rozpuszczone w małej ilości w oleju napędowym, atakuje znajdujące się w nim reaktywne związki. Daje to początek reakcjom łańcuchowym prowadzącym do przyspieszonego starzenia paliwa. Antyoksydanty blokują reakcje tego typu. Najczęściej wykorzystywanymi przeciwutleniaczami są fenole, aminy i ich pochodne; zwykle stosowane są one w stężeniu od 10 do $80 \mathrm{mg} / \mathrm{kg}$ [29, 42].

\section{Dodatki obniżające opory przeplywu}

Producenci oleju napędowego czasami stosują dodatki obniżające opory przepływu, aby umożliwić zwiększenie objętości cieczy, którą można przepompować w jednostce czasu. Wysokocząsteczkowe polimery wykorzystywane w tym celu zmieniają przepływ burzliwy cieczy płynącej w rurociągu, co może zwiększyć maksymalną prędkość przepływu od $20 \%$ do $40 \%$. Dodatki obniżające opory przepływu stosuje się zazwyczaj w stężeniu poniżej $15 \mathrm{mg} / \mathrm{kg}$ [41, 50].

\section{Stabilizatory (dodatki przeciwstarzeniowe)}

Stabilizatory zapobiegają reakcjom kwasowo-zasadowym, które mogą zachodzić w oleju napędowym, zwłaszcza w trakcie dhugotrwałego przechowywania. Zwykle są to silnie zasadowe aminy, które reagują ze słabo kwaśnymi związkami z wytworzeniem niereaktywnych, rozpuszczalnych w paliwie produktów. Stosowane są w stężeniu od 50 do $150 \mathrm{mg} / \mathrm{kg}[38,49]$.

\section{Markery}

Jedynym zadaniem tych dodatków jest umożliwienie rozpoznania rodzaju paliwa. W celu odróżnienia oleju napędowego od opałowego (ze względów np. podatkowych) dodawane są do tego pierwszego tzw. markery, które najczęściej są związkami azopochodnymi [28, 51]. 


\section{Podsumowanie}

Powyżej przedstawiono typowy skład pakietu dodatków uszlachetniających do olejów napędowych. Jak widać, jest to skomplikowana mieszanina wielu różnego typu związków chemicznych. Paliwo bez wymienionych wyżej dodatków jest zupełnie nieprzydatne do użycia w dzisiejszych samochodach z silnikami Diesla. Tylko dzięki zastosowa- niu tak niewielkiej ilości dodatków (w sumie około 1,5 g/kg paliwa) następuje przemiana mieszaniny węglowodorów w nowoczesne paliwo, które dla przeciętnego kierowcy tankującego je na stacji benzynowej i tak jest tylko żółtą cieczą o charakterystycznym zapachu, za którą trzeba coraz więcej płacić.

Prosimy cytować jako: Nafta-Gaz 2017, nr 3, s. 208-213, DOI: 10.18668/NG.2017.03.09

Artykuł nadesłano do Redakcji 1.12.2016 r. Zatwierdzono do druku 31.01.2017 r.

\section{Literatura}

[1] Arcoumanis C.: Internal Combustion Engines. Academic Press, 1988.

[2] Atmanli A.: Effects of a cetane improver on fuel properties and engine characteristics of a diesel engine fueled with the blends of diesel, hazelnut oil and higher carbon alcohol. Fuel 2016, vol. 172, s. 209-217.

[3] Beck Á., Pölczmann G., Eller Z., Hancsók J.: Investigation of the effect of detergent-dispersant additives on the oxidation stability of biodiesel, diesel fuel and their blends. Biomass and Bioenergy 2014, vol. 66, s. 328-336.

[4] Bücker F., Barbosa C.S., Quadros P.D., Krüger Bueno M., Fiori P., Huang C., Guedes Frazzon A.P., Ferrão M.F., de Oliveira Camargo F.A., Bento F.M.: Fuel biodegradation and molecular characterization of microbial biofilms in stored diesel/biodiesel blend $B 10$ and the effect of biocide. International Biodeterioration \& Biodegradation 2014, vol. 95, s. 346-355.

[5] Ertunc Tat M.: Cetane number effect on the energetic and exergetic efficiency of a diesel engine fuelled with biodiesel. Fuel Processing Technology 2011, vol. 92, s. 1311-1321.

[6] Fazal M.A., Haseeb A.S.M.A., Masjuki H.H.: Effect of different corrosion inhibitors on the corrosion of cast iron in palm biodiesel. Fuel Processing Technology 2011, vol. 92, s. 2154-2159.

[7] Folkson R.: Alternative Fuels and Advanced Vehicle Technologies for Improved Environmental Performance: Towards Zero Carbon Transportation. Woodhead Publishing, 2014.

[8] Ghosh P., Das M.: Study of the influence of some polymeric additives as viscosity index improvers and pour point depressants - Synthesis and characterization. Journal of Petroleum Science and Engineering 2014, vol. 119, s. 79-84.

[9] Goldsborough S.S., Johnson M.V., Banyon C., Pitz W.J., McNenly M.J.: Experimental and modeling study of fuel interactions with an alkyl nitrate cetane enhancer, 2-ethyl-hexyl nitrate. Proceedings of the Combustion Institute 2015, vol. 35, s. $571-579$.

[10] Ileri E.: Experimental study of 2-ethylhexyl nitrate effects on engine performance and exhaust emissions of a diesel engine fueled with n-butanol or 1-pentanol diesel-sunflower oil blends. Energy Conversion and Management 2016, vol. 118, s. 320-330.

[11] Markowski J.: Badanie stabilności nowych dodatków FBC oraz uszlachetnionych tymi dodatkami paliw. Nafta-Gaz 2011, nr 10, s. 736-741.

[12] Markowski J.: Dyspersja tlenków żelaza - aktualny stan wiedzy. Nafta-Gaz 2011, nr 4, s. 282-287.

[13] Ranney R.W.: Fuel additives for internal combustion engines: recent developments. Noyes Data Corp., 1978.

[14] Rashedul H.K., Masjuki H.H., Kalam M.A., Ashraful A.M., Ashrafur Rahman S.M., Shahir S.A.: The effect of additives on properties, performance and emission of biodiesel fuelled com- pression ignition engine. Energy Conversion and Management 2014, vol. 88, s. 348-364.

[15] Sarin A., Arora R., Singh N.P., Sarin R., Malhotra R.K., Sharma M., Khan A.A.: Synergistic effect of metal deactivator and antioxidant on oxidation stability of metal contaminated Jatropha biodiesel. Energy 2010, vol. 35, s. 2333-2337.

[16] Soldi R.A., Oliveira A.R.S., Barbosa R.V., César-Oliveira M.A.F.: Polymethacrylates: Pour point depressants in diesel oil. European Polymer Journal 2007, vol. 43, s. 3671-3678.

[17] Stelmachowski P., Kopacz A., Jakubek T., Indyka P., Markowski J., Wojtasik M., Ziemiański L., Krasodomski W., Żak G., Sojka Z., Kotarba A.: Insights into Structure, Morphology and Reactivity of the Iron Oxide Based Fuel Borne Catalysts. Topics in Catalysis 2016, nr 5, s. 1-7.

[18] Stelmachowski P., Legutko P., Kopacz A., Jakubek T., Indyka P., Pietrzyk P., Wojtasik M., Markowski J., Krasodomski W., Ziemiański L., Żak G., Sojka Z., Kotarba A.: Role of chain length of the capping agents of iron oxide based fuelborne catalysts in the enhancement of soot combustion activity. Applied Catalysis B: Environmental 2016, vol. 199, s. 485-493.

[19] The Consulting Company of DIW Berlin: Fuel Consumption in Road Traffic. DIW Economic Bulletin 2015, 36, https:// www.diw.de/documents/publikationen/73/diw 01.c.513315. de/diw econ bull 2015-36.pdf (dostep: październik 2016).

[20] The European Automobile Manufacturers' Association (ACEA): Passenger Car Fleet by Fuel Type. Strona internetowa ACEA, http:/www.acea.be/statistics/tag/category/passenger-car-fleet-by-fuel-type, (dostep: październik 2016).

[21] The International Council on Clean Transportation (ICCT): European Vehicle Market Statistics. Pocketbook 2015/16. http:/ www.theicct.org/sites/default/files/publications/ICCT_EU-pocketbook_2015.pdf, (dostęp: październik 2016).

[22] Tsanaktsidis C.G., Favvas E.P., Scaltsoyiannes A.A., Christidis S.G., Katsidi E.X., Scaltsoyiannes A.V.: Natural resins and their application in antifouling fuel technology: Part I: Improving the physicochemical properties of diesel fuel using natural resin polymer as a removable additive. Fuel Processing Technology 2013, vol. 114, s. 135-143.

[23] Woodyard D.: Pounder's Marine Diesel Engines and Gas Turbines, Ninth Edition. Butterworth-Heinemann 2009.

\section{Patenty}

[24] Patent CA 2221087 Diesel fuel and dispersant compositions and methods for making and using same, 1997.

[25] Patent CN 103865566 High-efficiency low-temperature diesel oil demulsifier and industrial using method thereof, 2014.

[26] Patent CN 104403706 A new type of diesel wax crystal dispersant, 2014 
[27] Patent CN 1204682 Demulsification method for purified diesel oil with alkaline cleaning electricity, 1998.

[28] Patent EP 0385441 Marker for petroliferous products, 1993.

[29] Patent EP 1350833 Specific antioxidant combination for diesel engine lubricating compositions, 1999.

[30] Patent EP 2417231 Cold temperature stable biocidal composition, 2009.

[31] Patent GB 24153 Improvements in and relating to the injection of liquid fuel in internal combustion engines, 1913.

[32] Patent PL 215447 Sposób wytwarzania modyfikowanych alkenylobursztynoimido-amidów, 2012.

[33] Patent US 2009/0077869 Diesel fuel additive compositions for prolonged antistatic performance, 2007.

[34] Patent US 2696428 Metal deactivators for hydrocarbon oils, 1951.

[35] Patent US 3173770 Metal deactivators for organic materials, 1960.

[36] Patent US 3382055 Polyalkylethyleneoxide pour point depressant additive, 1965.

[37] Patent US 3464627 Electromagnetic fuel-injection valve, 1969.

[38] Patent US 3490882 Stabilized distillate fuel oils and additive compositions therefor, 1970.

[39] Patent US 4720350 Oxidation and corrosion inhibiting additives for railway diesel crankcase lubricants, 1986.

[40] Patent US 4737159 Corrosion inhibitor for liquid fuels, 1984.

[41] Patent US 4861504 Oil additive having reduced lacquer forming tendencies, 1988.

[42] Patent US 5152909 Antioxidant/corrosion resistant additive for railway diesel crankcase lubricants, 1991.

[43] Patent US 5192336 Anti-foam diesel fuel, 1993.

[44] Patent US 7942941 Pour point depressant additives for oil compositions, 2004.
[45] Patent US 8349033 Diesel fuel, diesel fuel additive, and associated method for using the same, 2007.

[46] Patent WO 2001/088064 Anti-static lubricity additive for ultralow sulfur diesel fuels, 2011.

[47] Patent WO 2013/093100 Organic nitrates as ignition enhancers, 2013.

[48] Zgłoszenie patentowe P.398294 Wielofunkcyjny pakiet dodatków do olejów napędowych, 2012

[49] Zgłoszenie patentowe US 2010/0083564 Diesel Fuel Composition, 2010.

[50] Zgłoszenie patentowe US 2016/0024411 Additives for improving the resistance to wear and to lacquering of diesel or biodiesel fuels, 2012.

[51] Zgłoszenie patentowe WO 2014/083186 Improved fuel markers, 2014.

\section{Akty prawne i normatywne}

[52] Norma PN-EN 590 Paliwa do pojazdów samochodowych - Oleje napędowe - Wymagania i metody badań, 2011.

[53] Worldwide Fuel Charter, Fifth Edition, 2013.


Mgr inż. Jarosław MARKOWSKI Asystent w Zakładzie Dodatków i Nowych Technologii Chemicznych. Instytut Nafty i Gazu - Państwowy Instytut Badawczy ul. Lubicz 25 A

31-503 Kraków

E-mail: jaroslaw.markowski@inig.pl

\section{OFERTA}

\section{ZAKŁAD DODATKÓW I NOWYCH TECHNOLOGII CHEMICZNYCH}

Zakres działania:

- opracowywanie i doskonalenie technologii wytwarzania:

» dodatków uszlachetniających do płynnych paliw węglowodorowych i biopaliw,

» dodatków stosowanych podczas wydobycia, transportu i magazynowania ropy naftowej i gazu ziemnego,

» dodatków do paliw stałych, ze szczególnym uwzględnieniem komponentów pochodzących ze źródeł alternatywnych (gliceryna, odpady, itp.)

» specjalistycznych środków stosowanych w przemyśle;

- $\quad$ ocena jakości i przydatności do stosowania oraz ekspertyzy i doradztwo w zakresie dodatków i pakietów dodatków uszlachetniających do paliw i biopaliw;

- $\quad$ badania w zakresie nowych technologii chemicznych w przemyśle wydobywczym i rafineryjnym;

- $\quad$ badania niestandardowe i identyfikacyjne na potrzeby ekspertyz;

- badania nad wykorzystaniem nanoproduktów w przemyśle wydobywczym i rafineryjnym, opracowywanie i doskonalenie ich technologii;

- $\quad$ opracowywanie i walidacja nowych metod analiz dodatków uszlachetniających do paliw, biopaliw, ropy naftowej i gazu ziemnego;

- badania właściwości fizykochemicznych dodatków uszlachetniających do paliw i olejów smarowych.

Kierownik: dr Leszek Ziemiański

Adres: ul. Łukasiewicza 1, 31-429 Kraków

Telefon: 126177527

Faks: 126177522

E-mail: leszek.ziemianski@inig.pl

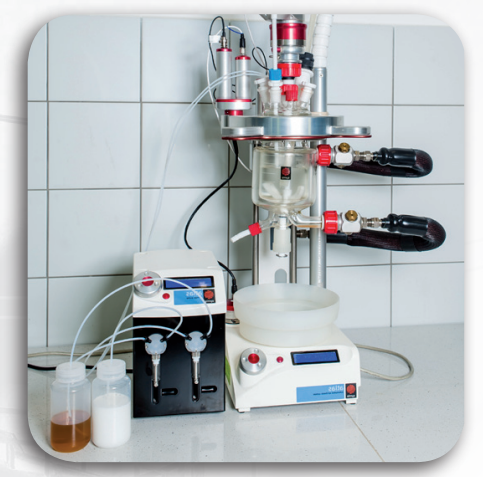

